УДК 378

DOI:10.15330/esu.14.13-21

\section{Тетяна Комінарецьь,}

кандидат філологічних наук, доцент,

Комунальний вищий навчальний заклад

"Херсонська академія неперервної освіти"

Херсонської обласної ради (м. Херсон, Україна)

Tatiana Kominarets,

Candidateof philological sciences ( $\mathrm{PhD})$, Associate

Professor, Communal Higher Educational Institution

"Kherson Academy of Continuing Education"

(Kherson, Ukraine)

ttyaanaa63@gmail.com

\title{
АКТУАЛЬНІСТЬ КОМПЕТЕНТНІСНОГО ПІДХОДУ В СУЧАСНОМУ ОСВІТНЬОМУ ПРОЩЕСІ У РУСЛІ ПЕДАГОГІЧНОЇ СПАДЩИНИ В.О.СУХОМЛИНСЬКОГО
}

\section{ACTUALITY OF THE COMPETENCY APPROACH IN THE MODERN EDUCATIONAL PROCESS AND IN THE PEDAGOGICAL HERITAGE OF V.O. SUKHOMLYNSKYI}

Стаття присвячена актуальності компетентнісного підходу в сучасній украйнській освіті в порівняния $і$ зв 'язку з класичною педагогікою В.Сухомлинського.

Метою сучасної світа е формування у учня вміння $i$ бажання вчитися впродовж иття, праџювати в команді, здатність до самозміни $і$ саморозвитку на основі рефлексивної самоорганізачії. Компетентнісний підхід, який лежить в основі Концетиї Нової української иколи, Державного стандарту початкової иколи, дозволяе ефективно виріиувати зазначені завдання, використовуючи при чьому сучасні педагогічні технологіі.

Школа мае стати не підготовчим етапом до життя, а самим жсттям; сприяти становленню особистості, як твория і проектувальника власного життя.

До важливих умов, які сприяють повночінному розвитку дітей, В. Сухомлинський відносить відповідність методів навчання, структури уроку, взагалі всіх організачійних та психолого-педагогічних елементів навчальній меті уроку, иоого освітньовиховним $i$ розвивальним завданиям та змісту

Особливість у використанні інтерактивних методів полягає в тому, ио освітній прочес відбувається за умови постійної активної взаємодії учнів та направляючой, корегуючої ролі педагога. Це - співнавчания, взасмонавчания (колективне, групове, навчания в співпрачі), де учень і вчитель є рівноправними, рівнозначними суб 'єктами прочесу.

Під час інтерактивного навчания учні вчаться бути демократичними, спілкуватися з іниими людьми, креативно мислити, приймати продумані рімення, виховуються ємпатія та толерантність по відноиенню до оточуючих. Застосовування активних форм занять в значній мірі сприяють формуванню компетентнісного підходу в навчанні.

Однією з ключових чінностей визначеної діяльності $е$ розвиток творчого $i$ критичного мислення, набуття досвіду та інструментарію дослідниької діяльності, самостійного поиуку, тобто орієнтачія не стільки на знання, скільки на набуття учнями позитивного досвіду самостійної роботи.

Спрямовуючи освітній прочес на формування життєвих $i$ предметних компетентностей у учнів, згідно Державного стандарту початкової освіти, педагог формуе навички практичного використання здобутих під час навчання знань та вмінь. Зазначені компетениії дають можливість дитині орієнтуватись у соиіумі та виріиувати проблеми, які ставить перед ним життя.

Ключові слова: компетентнісиий підхід, Концепція Нової украйнськой иколи, B. О. Сухомлинський, цінність дитинства, інтерактивні засоби навчання, дослідницька діяльність, критичне мислення. 
The purpose of modern education is the formation of a student's ability and desire to study throughout his whole life, to work in a team, the ability to self-change and to self-develop on the basis of the reflexive self discipline. The competent approach that underlies the Concept of the New Ukrainian School, the State Standard of Primary School, allows to effectively address these tasks using modern pedagogical technologies.

The school should become a non-preparatory stage for life, but the life itself; to promote the formation of personality, as the creator and designer of the person's own life.

To the important conditions that promote the full development of children, $V$. Sukhomlinsky submits the correspondence of teaching methods, the structure of the lesson, all organizational and psychological and pedagogical elements of the educational purpose of the lesson, its educational and developmental tasks and the content.

The peculiarity of the use of interactive methods is that the educational process takes place under the condition of the constant active interaction of students and the directional, corrective role of the teacher. It is co-education, mutual learning (collective, group, studying in cooperation), where the student and teacher are equal partners of this process.

During the interactive learning, students learn to be democratic, to communicate with others, to think creatively, to make informed decisions, to cultivate empathy and tolerance towards others. The use of active forms of interaction greatly contributes to the development of a competent approach to learning.

One of the key values of a particular activity is the development of creative and critical thinking, the acquisition of experience and the research tools, the independent seeking for information, that is, putting the emphasis not so much on knowledge, but on acquiring students a positive experience through an independent work.

By directing the educational process to the formation of vital and substantive competences in students, in accordance with the state standards of elementary education, the teacher acquires the skills of the practical use during the training. These competencies give the child the opportunity to navigate the society and solve the problems that he or she faces.

The article is devoted to the relevance of the competence approach in contemporary Ukrainian education in comparison with the classical pedagogy V. Sukhomlynsky.

Key words: competence approach, Concept of the New Ukrainian school, V.O. Sukhomlinsky, value of childhood, interactive means of teaching, research activity, critical thinking.

Метою сучасної освіта $є$ не тільки надання учням фіксованого набору знань, а й формування у нього вміння і бажання вчитися впродовж життя, працювати в команді, здатність до самозміни і саморозвитку на основі рефлексивної самоорганізації. Компетентнісний підхід, який лежить в основі Концепції Нової української школи, Державного стандарту початкової школи, дозволяє ефективно вирішувати зазначені завдання, використовуючи при цьому сучасні та класичні педагогічні технології.

Успішне оволодіння учнями змісту знань багато в чому залежить від умілого використання методів, які викликають високу пізнавальну активність учнів, методів, що забезпечують розвивальний характер навчання. Успішність навчального процесу залежить і від самого учня, від його бажання працювати, активності процесу пізнання на уроці. Сучасний процес пізнання передбачає партнерство між учителем і учнем, що поширює значення інтерактивного підходу до освітнього процесу. Учень має стати активним учасником цього процесу, формувати власні уміння та навички така вимога часу

Одним із провідних напрямів реформування початкової освіти на сучасному етапі $\epsilon$ впровадження інноваційних технологій, спрямованих на підвищення в учнів інтересу до освітньої діяльності, розвитку в них творчих здібностей. 
Мета статті - обгрунтувати значення комптентнісного підходу в освітньому процесі, як вимоги часу, у формуванні особистості сучасного учня через призму педагогічних думок В. О. Сухомлинського.

"Вік математики, чуєш на кожному кроці, вік електроніки, вік космосу... Всі ці вирази не відображають суті того, що діється в наш час. Світ вступає у вік Людини. Людина - ось, що головне", - писав В. Сухомлинський [13, с. 45].

Школа має стати не підготовчим етапом до життя, а самим життям; сприяти становленню особистості, як творця і проектувальника власного життя, гармонізації і гуманізації взаємин між учнями і педагогами, школою і родиною на основі ідеї самоцінності дитинства, діалогу, усвідомлення вибору особистістю життєвого шляху [6].

Концепція нової Української школи побудована на наступних принципах:

1. Презумпція талановитості дитини.

Забезпечення рівного доступу до освіти, заборона будь-яких форм дискримінації. Не допускатиметься відокремлення дітей на підставі попереднього відбору на індивідуальному, груповому та інституційному рівнях.

2. Цінність дитинства.

Відповідність освітніх вимог віковим особливостям дитини, визнання прав дитини на навчання через діяльність, зокрема гру.

3. Радість пізнання.

Організація пізнавального процесу, який приноситиме радість дитині, обмеження обсягу домашніх завдань для збільшення часу на рухову активність і творчість дитини. Широке використання в освітньому процесі дослідницької та проектної діяльності.

4. Розвиток особистості.

Замість "навченої безпорадності" - плекання самостійності та незалежного мислення. Підтримка 3 боку вчителя/вчительки розвиватиме у дітей самоповагу та впевненість у собі.

5. Здоров'я.

Формування здорового способу життя і створення умов для фізичного й психоемоційного розвитку, що надзвичайно важливо для дітей молодшого шкільного віку.

6. Безпека.

Створення атмосфери довіри і взаємоповаги. Перетворення школи на безпечне місце, де немає насильства і цькування [7].

Дитинство має важливе значення у суспільстві та культурі, оскільки не тільки закладає основи розвитку майбутніх поколінь, а й визначає рівень соціокультурного розвитку сучасного суспільства. Період дитинства - це справді “час долі" в житті людини, коли вплив об'єктивних чинників розвитку максимально великий, а свідомість у самовизначенні та самовихованні перебуває лише в процесі становлення і вимагає певних соціальних умов (включаючи педагогічне сприяння) для розвитку.

У педагогічній спадщині В. Сухомлинського категорія дитинства набуває особливого трактування і звучання: він підкреслює, що “дитинство - найважливіший період людського життя, не підготовка до майбутнього життя, а справжнє, яскраве, самобутнє неповторне життя...” [10, с. 15].

До важливих умов, які сприяють повноцінному розвитку дітей, В. Сухомлинський відносить відповідність методів навчання, структури уроку, взагалі всіх організаційних та психолого-педагогічних елементів навчальній меті уроку, його освітньовиховним і розвивальним завданням та змісту. 
В. Сухомлинський підкреслював, що виняткову роль відіграє вміння вчителя скерувати хід думки учнів так, щоб вони активно, зосереджено прагнули побачити невидиме, зрозуміти приховане, розгледіти незвичайне у звичайному [4].

Різноманітним аспектам педагогічної спадщини В. Сухомлинського присвячені історико-педагогічні дослідження Н. Безлюдної, Г. Бондаренко, М. Дубінки, Г. Калмикова, В. Кіндрата, В. Кравцова, О. Савченко, О. Сухомлинської, Г. Ткаченко та інших учених.

“Щасливими можна назвати тих учителів, які дійшли зі своїм класом до того етапу, коли вони можуть сказати: "Незалежно від моєї присутності, клас працює. Група досягла самостійності”, - говорила Марія Монтессорі.

Організація групової діяльності учнів, як засіб використання інтерактивних методів на рівнях: “учень-учитель", “учень-учень" є результатом впливу двох складових: викладача і лідера проектної групи. Якісно змінюються функції педагога. Він вже не є тільки джерелом знань, а є організатором спільної діяльності. Від його діяльності багато в чому залежить попередній етап навчальної роботи - самостійна робота в процесі самопідготовки. На лідера проектної групи покладасться відповідальність за результат роботи учнів та презентація результатів роботи. Учитель спільно з учнями регулює напрямки діяльності, ступінь відповідальності. Особливе значення має керівництво школярами під час обговорення результатів спільної діяльності і пошуки відповідей на питання своєї групи.

Сам термін “інтерактивне навчання” відносно новий: в науковий обіг у 1975 p. його вводить німецький дидакт Ганс Фріц. Якщо йти за етімологією, то слово “інтерактив" прийшло до нас з англійської мови від слова "inter" - взаємний i "act" діяти. Одже, інтерактивний - здатний до взаємодії, діалогу. Інтерактивне навчання це специфічна форма організації пізнавальної діяльності, яка має передбачувану мету - створити комфортні умови навчання, за яких кожен учень відчуває свою успішність, інтелектуальну спроможність [8, с. 9].

Особливість у використанні інтерактивних методів полягає в тому, що освітній процес відбувається за умови постійної активної взаємодії учнів та направляючої, корегуючої ролі педагога. Це - співнавчання, взаємонавчання (колективне, групове, навчання в співпраці), де учень і вчитель $\epsilon$ рівноправними, рівнозначними суб'єктами процесу. Організація інтерактивного навчання передбачає моделювання життєвих ситуацій, вміння бачити та спільно розв'язувати життєві проблеми. Воно ефективно сприяє формуванню навичок i вмінь, виробленню цінностей, створенню атмосфери партнерства, взаємодії.

Характерними рисами інтерактивного навчання вважають: побудову навчання як розв'язання серії взаємопов'язаних проблемних ситуацій; переважно групова форма роботи учнів на уроці; опора на особистий досвід; відкритість навчання, відсутність раз на завжди визначеного рішення; співробітництво різних рівнів (вчительгрупа, вчитель-учень, учень-група, учень-учень); широкий зворотній зв'язок - учень бачить реакцію вчителя, може проконсультуватися в будь-який момент навчання; емоційне піднесення, розкутість; діалог - основний елемент навчання [2].

Сучасне українське суспільство вимагає виховання самостійних, ініціативних, відповідальних громадян, здатних ефективно взаємодіяти у виконанні соціальних, прагматичних, та виробничих завдань. Досягнення цієї мети потребує всебічного розвитку особистісних якостей, творчих здібностей та критичного мислення учня, уміння працювати 3 інформацією, навчатися впродовж життя, розв'язувати проблеми, орієнтуватися в житті суспільства. 
Під час інтерактивного навчання учні вчаться бути демократичними, спілкуватися 3 іншими людьми, креативно мислити, приймати продумані рішення, виховуються ємпатія та толерантність по відношенню до оточуючих.

Застосовування активних форм занять в значній мірі сприяють формуванню компетентнісного підходу в навчанні.

Випускник школи повинен вміти самостійно мислити, бачити i творчо вирішувати виникаючі проблеми. Ця умова особливо актуальна в сучасному динамічному інформаційному просторі. Але учні не завжди можуть орієнтуватися у величезному потоці нової інформації, вибирати з неї необхідні данні і, а потім результативно використовувати їх у своєї роботі. Рішенням у цієї ситуації $є$ активна участь здобувачів освіти в освітньому процесі - дослідницька діяльність.

Однією 3 ключових цінностей визначеної діяльності $\epsilon$ розвиток творчого i критичного мислення, набуття досвіду та інструментарію дослідницької діяльності, самостійного пошуку, тобто орієнтація не стільки на знання, скільки на набуття учнями позитивного досвіду самостійної роботи.

Звернення до багаторічного досвіду педагогічної діяльності В. Сухомлинського дає підстави стверджувати, що проблема дослідної роботи вчителя та учнів - одна 3 найважливіших у педагогічній спадщині великого педагога. На думку вченого, навіть підготовка до школи повинна починатися не 3 навчання читанню та письму, а $з$ практичної пізнавальної діяльності дитини. "Уже в 5-6-річному віці виділяється група дітей, яких ми називаємо дослідниками. Вони досліджують рослинний світ у саду, на городі. Ось малюки приходять у березні до школи, а починати їм учитися ще через півтора року. Вони збираються через день-два, а потім і щодня в шкільній теплиці, у саду. Висівають насіння зернових культур (пшениці, гречки, ячменю, проса) і плодових дерев (яблуні, груші, персика, вишні, черешні), висаджують чубуки винограду i живці троянд. Поливають грунт за допомогою насосів, спеціально зроблених для них, малят. Невдовзі з'являються перші сходи зернових культур, потім - плодових дерев, з'являється листя на живцях. Чим значніші результати цієї праці, тим більше в дітей запитань: чому одна рослина дає врожай уже першого року, а інша - тільки черезкілька років? Чому персик за літо виростає на метр, а на дубку виростають лише чотири листочки? Чому колос пшениці не схожий на волоть проса? Чому в кавуна насіння в “солодкій коморі”, а в пшениці ніякої “комори” немає? У хвилину напруженого мислення над кожним 3 цих запитань думка дитини тисячі разів умить переключається, предмет досліджусться 3 усіх боків. Дитина вчиться думати, спостерігаючи, і спостерігати, думаючи, - в цьому й полягає зміст уроків мислення" [12, с. 239].

У Державному стандарті початкової освіти однією 3 ключових компетентностей визначена наступна: “...компетентності у галузі природничих наук, техніки і технологій, що передбачають формування допитливості, прагнення шукати i пропонувати нові ідеї, самостійно чи в групі спостерігати та досліджувати, формулювати припущення i робити висновки на основі проведених дослідів, пізнавати себе і навколишній світ шляхом спостереження та дослідження" [9].

Таким чином, дослідницька діяльність безпосередньо пов'язана с формуванням компетентнісного підходу до освітнього процесу.

Дослідницька діяльність - діяльність учнів, пов'язана $з$ рішенням творчої, проблемно-пошукових завдань із заздалегідь невідомим рішенням i передбачає наявність основних етапів, характерних для дослідження в науковій сфері: постановку проблеми, вивчення теорії, присвяченій даній проблематиці, підбору 
методик дослідження та практичне оволодіння ними, збір власного матеріалу, його аналіз i узагальнення, науковий коментар i власні висновки. Існують i iнші визначення дослідницької діяльності, наприклад: “Під дослідницькою діяльністю розуміється діяльність учнів, пов'язана з пошуком відповіді на творчу, дослідницьку задачу із заздалегідь невідомим рішенням і передбачає наявність основних етапів, характерних для дослідження в науковій сфері: постановку проблеми, вивчення теорії, присвяченій даній проблематиці, підбір методик дослідження та практичне оволодіння ними, збір власного матеріалу, його аналіз і узагальнення, науковий коментар і висновки" [1, с. 31].

Це означає, що педагогічна діяльність учителя має бути спрямована не лише на засвоєння учнями знань 3 відповідного навчального предмета, але й на розвиток пізнавальної активності учнів, навичок самостійного пошуку нестандартних рішень, тобто на формування в учнів дослідницьких умінь.

Теоретичні основи дослідницької технологіï, їі вплив на особистісний розвиток учнів розкриваються в роботах О. Анісімової, С. Бондар, А. Кіктенко, М. Пєхоти, Г. Цехмістрової. В їхніх працях розкривається сутність та зміст дослідницької

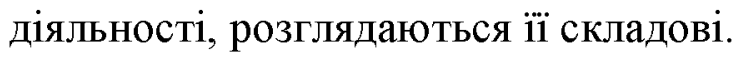

Невідємною частиною дослідницької діяльності учнів $\epsilon$ формування критичного мислення.

Критичне мислення - це головний вид інтелектуальної діяльності людини, що вимагає високого рівня розуміння, об’єктивності відносно інформації, що оточує нас, уміння з нею працювати

Особливістю у використанні методики критичного мислення у дослідницькій, проектній діяльності учнів $є$ :

- активізація їх індивідуальних розумових здібностей;

- формування дослідницьких навичок, що включають в себе вміння орієнтуватися в джерелах інформації, вибирати необхідні факти, критично оцінювати нові знання, робити висновки і узагальнення;

- стимулювання самостійної пошукової творчої діяльності, самоосвіти і самодисципліни.

Організація уроку за методикою критичного мислення через дослідницьку діяльність відрізняється від традиційних уроків, учні стають головними дійовими особами уроку. Форми побудови уроку можна використовувати різні.

Мета освітньої діяльності сучасної школи - не споживання учнем через зубріння формул або теоретичних положень, не запам'ятовування теорії i використання стереотипних навичок, а оволодіння науковою інформацією через практичну діяльність при якому кожен школяр зміг би вирішувати завдання шляхом використання засвоєних знань, умінь і навичок, тобто сформованих компетентностей.

Педагог на уроці повинен застосовувати такі форми і методи роботи, щоб учень був перш за все здобувачем знань, вмів шукати відповіді самостійно а не пасивно запам'ятовував знання під керівництвом учителя. При тому В. Сухомлинський зауважував, що активність має проявлятися найперше в активності розуму, в усвідомленні учнями основних причинно-наслідкових зв'язків навчального матеріалу. Саме цієї мети він досягав на заняттях школи Мислення, під час спостереження дітей за навколишнім світом 3 різними явищами природи. Під час цих занять педагог вводив у пізнавальну частину елементи гри, що робило їх більш привабливими і зрозумілими для дітей раннього шкільного віку. 
Одне з найважливіших завдань школи, вказував В. Сухомлинський, “навчити користуватися знаннями. Якщо набуті уміння i навички тільки засвоюються i не застосовуються на практиці, навчання поступово виходить зі сфери духовного життя дитини, неначе відділяється від ії інтересів і захоплень" [10].

I тут же підкреслює: “Дуже важливо, щоб мислення учнів грунтувалося на дослідженні, пошуках, щоб усвідомленню наукової істини передувало нагромадження, аналіз, зіставлення і порівняння фактів. Спостерігаючи явища i картини природи, дитина оволодіває формами й процесами мислення, збагачується поняттями, кожне 3 яких сповнюється реальним змістом причинно-наслідкових зв'язків, помічених гострим зором допитливого спостерігача".

Щоб навчальні вміння в дійсності були максимально наближеними до реальних завдань і умов і вільно варіювалися не тільки на заняттях, але і на практиці, в допомогу нам приходять власна пізнавальна активність дитини, яка робить вирішальний вплив на темп, глибину і міцність оволодіння навчальним матеріалом.

Пізнавальна активність в навчальній діяльності поряд зі свідомістю давно вважається однісю з провідних в теорії навчання.. В працях В.О. Сухомлинського, зокрема в його теорії розумового виховання, прослідковується розробка елементів інтерактивного навчання. Успіх розумового виховання в процесі навчання визначають такі фактори як: багатство всього духовного життя школи; духовне багатство вчителя, широта його світогляду, його ерудиція, культура; зміст навчальних програм. В.О. Сухомлинський наголошував, що виняткового значення слід надавати дослідницькому характеру розумової праці: спостерігаючи, думаючи, вивчаючи, зіставляючи діти знаходять істину або ж бачать, що для відкриття істини потрібні нові спостереження, потрібне читання, експериментування [3].

В силу історичних обставин протягом тривалого періоду на основі знання особливостей педагогіки, діалектичної логіки і діалектичного методу пізнання був визначений термін - принцип свідомості і активності. "3 цього слідує, що необхідно поставити процес навчання так, щоб учні свідомо засвоювали знання, набували вміння та навички в активній діяльності, розвивали їх в пізнавальній праці" [14, c. 153].

Одним із методів активного навчання, які зазначені у Концепщії Нової української школи $є$ метод проблемного навчання. Проблемну ситуацію створюють за допомогою проблемних питань чи завдань, логічно пов'язаних зі змістом матеріалу. Проблеми підбирає посильні, спираючись на досвід і на знання, які вже має дитина, спрямовуючи іiі думку в русло знань, що потрібні для розв'язання проблеми. Учні спочатку під керівництвом вчителя а потім i самостійно аналізують раніше опанований навчальний матеріал, відшукують відповіді для розв'язання поставленої проблеми та формулюють обгрунтовані висновки. Таку форму роботи вчитель використовує під час вивчення нового матеріалу, на уроках узагальнення і систематизації знань, в позакласних заходах. Особливо цікаві результати такій вид роботи дає під час диспутів і дискусій, тому що вимагає вміння працювати з інформацією.

Концепщія загальної середньої освіти (12-річна школа) проголошує освіту XXI століття освітою для людини. Її стрижень - розвивальна, культуро творча домінанта, виховання відповідальної особистості, яка здатна до самоосвіти і саморозвитку, вміє критично мислити, опрацьовувати різноманітну інформацію, використовувати набуті знання й уміння для творчого розв'язання проблем, прагне змінити на краще своє життя та життя своєї країни [2, с. 57] 
Павлиський педагог у своїх творах охоплював цілий ряд проблем, які не втратили актуальності і в наш час. Це - проблема розвитку творчої особистості вчителя та школяра, дослідницький процес здобування знань, уміння учнів вчитися, збереження здоров'я дітей, процес підготовки майбутніх вчителів, проблема наступності між дошкільною та початковою освітою та вихованням тощо.

Сухомлинський був переконаний у тому, що педагогічна теорія розвивається до тих пір, поки вона живе, збагачується й удосконалюється в досвіді, новаторській праці тисячі педагогів. Тому він наполегливо добивався, щоб кожний учитель, вихователь був не просто "споживачем" педагогічних знань, а дослідником і реалізатором. Він писав: “Справжній учитель, не може жити без творчості; педагогічна праця за своєю природою, за внутрішньою логікою не мислима без елемента наукового дослідження, вона завжди має бути осяяна світлом і виступати як джерело нової думки, нових теоретичних узагальнень. Якщо ви хочете, щоб педагогічна праця давала вчителеві радість, щоб повсякденне проведення уроків не перетворилось на нудну, одноманітну повинність, ведіть кожного вчителя на щасливу стежку дослідження" [11, с. 64].

Характерною особливістю роботи учнів 3 творчим вчителем, писав В.О.Сухомлинський, є дослідницький підхід до предмета вивчення. За таким підходом учневі не даються готові висновки чи доведення правильності тієї чи іншої істини. Учитель мотивує учнів до висунення декількох пояснень, пошуку в самій діяльності підтвердження й спростування висунутих гіпотез. Учні доводять одне і спростовують інше - як практикою у вузькому розумінні цього слова, тобто безпосередніми спостереженнями над фактами i явищами, так і опосередкованим мисленням. Знання при цьому не пасивно засвоюються, як звикли говорити вчителі, а здобуваються активними зусиллями. Отримані у такий спосіб знання стають переконаннями, і учні дорожать ними [5].

Висновок. Таким чином, спрямовуючи освітній процес на формування життєвих і предметних компетентностей у учнів, згідно Державного стандарту початкової освіти, педагог формує навички практичного використання здобутих під час навчання знань та вмінь. Зазначені компетенції дають можливість дитині орієнтуватись у соціумі та вирішувати проблеми, які ставить перед ним життя.

Творча спадщина В. О. Сухомлинського переконує нас у різноманітності педагогічних підходів до формування особистості учня. В наш час, коли освітня реформа має чітко визначене гуманістичне направлення, практична діяльність Василя Олександровича є не тільки надбанням української педагогіки але і надійним орієнтиром у вирішенні багатьох завдань, які ставить перед нами сучасність. Творчість Сухомлинського 3 кожним роком набуває практичного значення для педагогів та привертає до себе увагу наукової і педагогічної спільноти, як у нашій країні, так і за кордоном.

\footnotetext{
Література

1. Алексеев Н. Концепция развития исследовательской деятельности учащихся / Н. Алексеев, А. Леонтович, А. Обухов // Исследовательская работа школьников. - 2001. - № 1. - С. 24-34.

2. Баханов К. Традиції та інновації у навчанні історії : дидактичний словник-довідник / К.Баханов. - Запоріжжя : Просвіта, 2003. - 108 с.

3. Бугай В. Педагогічна спадщина В. О. Сухомлинського в умовах загальноосвітнього навчального закладу [Електронний ресурс]. - Режим доступу: http://visnyk.chnpu.edu.ua.

4. Волошин К. Педагогічна система В. Сухомлинського / К.О. Волошин // Наукові записки ТДПУ ім. В. Гнатюка: Педагогіка. - 2003. - №11. - С. 17-18.

5. Гузинець О. В. О. Сухомлинський про інноваційні технології навчання/ Науковий вісник МНУ імені В. О. Сухомлинського // Випуск 1.47 (114). - Режим доступу: http://irbis-nbuv.gov.ua.
} 
6. Державний стандарт загальної середньої освіти, затверджений постановою Кабінету Міністрів України від 16 листопада 2000 р. № 1717 // Освіта України. Нормативно-правові документи. Л. : Міленіум. - С. 117-118.

7. Концепція Нової української школи, затверджена розпорядженням Кабінету Міністрів України від 14 грудня 2016 p. № 988-р [Електронний режим]. - Режим доступу: http://dlse.multycourse.com. ua.

8. Побірченко Н. Інтерактивне навчання в системі освітніх технологій / Н. Побірченко, Г. Коберник // Початкова школа - 2004. - № 10. - С. 8-10.

9. Про затвердження Державного стандарту початкової освіти. Кабінет міністрів України (Постанова від 21 лютого 2018 р. № 87) [Електронний ресурс]. - Режим доступу: https://www.kmu.gov.ua.

10. Сухомлинський В. Павлиська середня школа / В. О. Сухомлинський // Вибрані твори в п'яти томах. - К. : Радянська школа, 1977. - Т. 4. - С. 7-390.

11. Сухомлинський В. Як виховати справжню людину / В. О. Сухомлинський // Вибрані твори : у 5 т. - Т. 2. - К. : Рад. школа, 1976. - С. 149-416.

12. Сухомлинський В. О. Вибрані твори в п’яти томах / В. О. Сухомлинський. - К. : Радянська школа, 1976. - Т. 3. -670 с.

13. Сухомлинський В. О. Розмова з молодим директором школи / В. О. Сухомлинський // Вибрані твори : в 5 томах. - Т. 4. - К. : Радянська школа, 1977. -670 с

14. Фридман Л. М. Психологический справочник учителя / Л. М. Фридман, И. Ю. Кулагина. - М. : Просвещение, 1991. - 288 с.

\section{References}

1. Alekseev N. Kontseptsyia razvytyia yssledovatelskoi deiatelnosty uchashchykhsia / N. Alekseev, A. Leontovych, A. Obukhov // Yssledovatelskaia rabota shkolnykov. - 2001 - № 1. - S. 24-34

2. Bakhanov K. Tradytsii ta innovatsii u navchanni istorii : dydaktychnyi slovnyk-dovidnyk / K.Bakhanov. - Zaporizhzhia : Prosvita, 2003. - 108 s.

3. Buhai V. Pedahohichna spadshchyna V. O. Sukhomlynskoho v umovakh zahalnoosvitnoho navchalnoho zakladu [Elektronnyi resurs]. - Rezhym dostupu: http://visnyk.chnpu.edu.ua.

4. Voloshyn K. Pedahohichna systema V. Sukhomlynskoho / K.O. Voloshyn // Naukovi zapysky TDPU im. V. Hnatiuka: Pedahohika. - 2003. - №11. - S. 17-18.

5. Huzynets O. V. O. Sukhomlynskyi pro innovatsiini tekhnolohii navchannia/ Naukovyi visnyk MNU imeni V. O. Sukhomlynskoho // Vypusk 1.47 (114). - Rezhym dostupu: http://irbis-nbuv.gov.ua.

6. Derzhavnyi standart zahalnoi serednoi osvity, zatverdzhenyi postanovoiu Kabinetu Ministriv Ukrainy vid 16 lystopada 2000 r. № 1717 // Osvita Ukrainy. Normatyvno-pravovi dokumenty. - L. : Milenium. - S. 117-118.

7. Kontseptsiia Novoi ukrainskoi shkoly, zatverdzhena rozporiadzhenniam Kabinetu Ministriv Ukrainy vid 14 hrudnia 2016 r. № 988-r [Elektronnyi rezhym]. - Rezhym dostupu: http://dlse.multycourse.com.ua.

8. Pobirchenko N. Interaktyvne navchannia $\mathrm{v}$ systemi osvitnikh tekhnolohii / N. Pobirchenko, H. Kobernyk // Pochatkova shkola - 2004. - № 10. - S. 8-10.

9. Pro zatverdzhennia Derzhavnoho standartu pochatkovoi osvity. Kabinet ministriv Ukrainy (Postanova vid 21 liutoho 2018 r. № 87) [Elektronnyi resurs]. - Rezhym dostupu: https://www.kmu.gov.ua.

10. Sukhomlynskyi V. Pavlyska serednia shkola / V. O. Sukhomlynskyi // Vybrani tvory v piaty tomakh. - K. : Radianska shkola, 1977. - T. 4. - S. 7-390.

11. Sukhomlynskyi V. Yak vykhovaty spravzhniu liudynu/V. O. Sukhomlynskyi // Vybrani tvory : u $5 \mathrm{t}$. - T. 2. - K. : Rad. shkola, 1976. - S. 149-416.

12. Sukhomlynskyi V. O. Vybrani tvory v piaty tomakh / V. O. Sukhomlynskyi. - K. : Radianska shkola, 1976. - T. 3. $-670 \mathrm{~s}$.

13. Sukhomlynskyi V. O. Rozmova z molodym dyrektorom shkoly / V. O. Sukhomlynskyi // Vybrani tvory : v 5 tomakh. - T. 4. - K. : Radianska shkola, 1977. $-670 \mathrm{~s}$.

14. Frydman L. M. Psykholohycheskyi spravochnyk uchytelia / L. M. Frydman, Y. Yu. Kulahyna. - M. : Prosveshchenye, 1991. $-288 \mathrm{~s}$. 